\title{
Childhood Grade III Meningioma
}

National Cancer Institute

\section{Source}

National Cancer Institute. Childhood Grade III Meningioma. NCI Thesaurus. Code C71303.

A grade III meningioma that occurs during childhood. 